\title{
BIOLOGICAL CHARACTERISTICS THAT INFLUENCE THE SEUROP SYSTEM CLASSIFICATION FOR CZECH FLECKVIEH AND HOLSTEIN BULL CARCASSES
}

\author{
R. Filipčík, J. Šubrt, M. Vyroubal \\ Received: February 3, 2006
}

\begin{abstract}
FILIPČÍK, R., ŠUBRT, J., VYROUBAL, M.: Biological characteristics that influence the SEUROP system classification for Czech fleckvieh and Holstein bull carcasses. Acta univ. agric. et silvic. Mendel. Brun., 2006, LIV, No. 2, pp. 31-40

The aim of this work was to analyse the influence of certain characteristics (aptitude, age, carcass weight, net daily gain, feeding) on the final carcass classification in the SEUROP system. 703 Czech Fleckvieh bulls and 642 Holstein bulls were studied. The animals were slaughtered and evaluated at a designated beef processing company. Combine aptitude carcasses shown significant differences between characteristics. Remarkable differences of group averages $(P>0,01)$ were established between farms and they were due to various rearing conditions. Also the levels of net daily gain between aptitudes were proved significantly. Holstein breed showed significant difference among The net daily gain $<500$ g.day $^{-1}$ and levels 551-600; 601-650 and above 651 g.day $^{-1}$. The SEUROP system is influenced the most by the feeding regime, which is described by a net daily gain in this work, and farm impact.
\end{abstract}

SEUROP, conformation, fat, cattle, aptitude, beef carcass, age, weight

The carcasses classification is done using the SEUROP system, a subjective classification of the conformation and fat on a carcass. The classification is done by trained experts at the end of the slaughtering line. The SEUROP system look for beef carcasses with high level of meat and relatively low fat contend. Subsequently the price has to correspond to the carcass quality. However the production of quality beef is affected by many factors, mainly of biological origin. The most important are the selection of a suitable breed, aptitude, sex, feeding, slaughtering weight and age. The influence of these points on beef quality was also dealt with by AUGUSTINI et al. (1992), according to them; important factors are age of slaughtering, rearing intensity and duration. BUREŠ et al. (2004) said that beef production, from the world point of view, is achieved by combine breeds. These breeds represent a good combination of beef and dairy cattle. Their priority is sufficient grow intensity at rear- ing, to have a higher slaughtering weight as well as a good carcass weight and production of low fat contend beef.

CHAMBAZ et at. (2003) studied the influence of Angus, Simmental, Charolais and Limousine on beef quality in relation with the fat contends changes in the Musculus longissimus dorsi and muscular marbling. Conformation and fat covering were assessed by Swiss classification, which correspond to the EUROP system. The Limousine carcasses were the best evaluated, placed at "E" class. ONENC (2004) compared the conformation and fattiness at Holstein, Swiss brown and East Red Anatol carcasses. Holstein and Swiss brown bulls reached higher quality.

Sex also influences weight and quality of transversely stripped muscles. The thickness in muscle fibres is less significant between sexes, although females generally have them finer then males. Direct heifer rearing is not too common in the Czech Repub- 
lic. Animals unsuitable for further breeding or over plus heifers are designated for meat stock as well as hybrid heifers crossed between dairy and beef cattle, if they are not used for the next breeding. Also heifers negatively selected from a beef herd are integrated to rearing, if there is no interest to expand and less animals are needed to revive the herd.

In the Czech Republic ox rearing probably will not get as popular as overseas, although in the last few years, due to the European trend agricultural production is more intensive, because of meat abundance in the market and to use extensive grasslands. So there is the possibility of conjoint oxen and heifers pasture rearing. Extensive rearing would take longer and it would lower the risk of over fattening, in certain circumstances it can have a good impact on a company's economy BUREŠ et al. (2004). ČUBOŇ et al. (2000) researched relations among sex, aptitude and Slovakian Fleckvieh classification. The result was the positive interrelation between grow intensity of body tissues and animal age, their grow intensity, aptitude and breeding conditions at the top level of feeding and breeding management. CHLÁDEK and INGR (2003) investigated the influence of slaughtering age and grow intensity in Holstein oxen. They were divided into two groups by their weight (till $430 \mathrm{~kg}$ and above $431 \mathrm{~kg}$ ) and into two groups by their net daily gain (till $1.050 \mathrm{~kg}$ and above $1.051 \mathrm{~kg}$ per day). The impact of these groups on slaughtering value was searched. The authors expect higher weight and bigger front quarter carcass parts at slaughtering. Higher grow intensity is followed by higher amount of kidney fat and could result in less proportion of some carcass parts. The influence of animal welfare at the slaughterhouse, the way of carcass hang and the sex, influence the carcass quality PIPEK at al. (2003). The $\mathrm{pH}$ and meat colour were analysed and cutting tests were done in the rump, sirloin and shoulder.

Feeding influence on a muscle fibre grows assessed FIEMS et al. (1995). GERHARDY (1995) specified the differences in the transverse muscle grow owing to various feeding. MANDELL et al. (1998) put together accrual of body weight with accrual of muscle tissue; beef aptitude is also influenced by quality and composition of feeding ration and animal constitution.

The age and weight of slaughtering are important factors influencing beef quality. It can be established from the work of CICALA et al. (1998) that the proportion of connecting tissue in muscle tissue grows proportionally with age and weight of bulls, though muscle fibre can occasionally decrease. KÖGEL (1990) learnt positive correlation $(\mathrm{r}=+0.55)$ between slaughtering weight and quality of carcasses. The relation between slaughtering weight and their final classification was also found out by ŠUBRT at al. (1999).

\section{MATERIALS AND METHODS}

The work studied 1345 beef bulls; from those 703 belong to combine aptitude cattle (Czech Fleckvieh] and 642 dairy cattle (Holstein). Both groups come from 11 farms of east Bohemia and Vysočina and were slaughtered (evaluated) in the same conditions in the same slaughterhouse.

The cattle weight data analysed were issued by a technician of SEUROP system for each beef cattle supplier. The lineage was rewritten from the cattle safe conduct.

Statistic analysis was done by SAS 8.2, where apart of basic statistic calculation, GLM procedure was used to figure multifactor analysis of variance with fixed effect, to explain the level of characteristics chosen in the final classification of carcasses, conformation and fattiness according to the SEUROP system.

$$
\begin{aligned}
& \mathbf{Y}_{\mathrm{ijklmn}}=\boldsymbol{\mu}+\mathbf{P}_{\mathbf{i}}+\mathbf{V}_{\mathbf{j}}+\mathbf{J U T}_{\mathbf{k}}+\mathbf{N P}_{\mathbf{1}}+\mathbf{V Z}_{\mathbf{m}}+\mathbf{e}_{\mathrm{ijklmn}}, \\
& \text { where: } \boldsymbol{\mu}= \text { the average value of meatiness and } \\
& \text { fatness } \\
&= \text { breed (1-Czech Fleckvieh, 2-Hol- } \\
& \text { stein) } \\
&= \text { slaughtering age }(1<550 \text { days, } 2-550 \\
& \text { to } 650 \text { days, } 3-651 \text { to } 700 \text { days, } 4> \\
&701 \text { days }) \\
& \mathrm{JUT}= \text { carcass weight }(1<310 \mathrm{~kg}, 2-311 \text { to } \\
&360 \mathrm{~kg}, 3-361 \text { to } 400 \mathrm{~kg}, 4>401 \mathrm{~kg}) \\
& \mathrm{NP}= \text { net daily gain }(1<500 \mathrm{~g} / \mathrm{day}, 2-501 \\
& \text { to } 550 \mathrm{~g} / \mathrm{day}, 3-551 \text { to } 600 \mathrm{~g} / \mathrm{day}, 4- \\
&601 \text { to } 650 \mathrm{~g} / \mathrm{day}, 5>651 \mathrm{~g} / \text { day }) \\
& \mathrm{VZ}= \text { rearing station }(1-11 \mathrm{farms}) \\
& \mathrm{e}_{\mathrm{ij} k l m n}= \text { residuum. }
\end{aligned}
$$

Abbreviations: $\overline{\mathrm{x}}$ mean; Sx standard deviation; $\mathrm{S} \overline{\mathrm{x}}$ standard error; V variation coefficient $\%$.

\section{RESULTS AND DISCUSSION}

Czech Fleckvieh bulls were slaughtered at an average age of 647.7 days and Holstein bulls at 624.3 days. Holstein carcasses were on average $13 \mathrm{~kg}$ heavier than Czech Fleckvieh carcasses. Holstein bulls had the higher weight due to the more intensive way of feeding at rearing season as shown in table I. Beef bulls of both breeds were classified with SEUROP system as class "U" according to conformation and as class 2 according to fatness. Variability within a group of carcasses is on the same level 28.0 respectively $28.5 \%$. The impact of the aptitude on the final conformation and fattiness classification is shown in table 
II. A strong difference was found between the breeds in the SEUROP system with $99 \%$ of mathematical expectation. The carcasses of Czech Fleckvieh were better assessed to the classes of conformation (2.87 points).

\section{I: Basic carcasses characteristics of Czech Fleckvieh (C) and Hol-} stein $(H)$ breed bulls

\begin{tabular}{|c|c|c|c|}
\hline \multirow{2}{*}{ Indicator } & & $\mathrm{C}$ & $\mathrm{H}$ \\
\hline & $\mathrm{n}$ & 703 & 642 \\
\hline \multirow{4}{*}{ Slaughter age (days) } & $\bar{x}$ & 647 & 624 \\
\hline & $s_{x}$ & 73.7 & 51.8 \\
\hline & $S_{\bar{x}}$ & 2.7 & 2.0 \\
\hline & $\mathrm{V}$ & 11.4 & 8.3 \\
\hline \multirow{4}{*}{ Weight of carcass (kg) } & $\bar{x}$ & 343 & 356 \\
\hline & $s_{x}$ & 39.5 & 46.6 \\
\hline & $S_{\bar{x}}$ & 1.4 & 1.8 \\
\hline & $\mathrm{V}$ & 11.5 & 13.1 \\
\hline \multirow{4}{*}{ Daily net weight gain (g) } & $\bar{x}$ & 536 & 572 \\
\hline & $s_{x}$ & 76.2 & 69.4 \\
\hline & $S_{\bar{x}}$ & 2.8 & 2.7 \\
\hline & V & 14.2 & 12.1 \\
\hline \multirow{4}{*}{$\begin{array}{l}\text { SEUROP conformation } \\
\text { (point)* }\end{array}$} & $\bar{x}$ & 3.0 & 3.1 \\
\hline & $s_{x}$ & 0.2 & 0.3 \\
\hline & $S_{\bar{x}}$ & 0.01 & 0.01 \\
\hline & $\mathrm{V}$ & 7.8 & 12.2 \\
\hline \multirow{4}{*}{$\begin{array}{l}\text { SEUROP fatness } \\
\text { (point)** }\end{array}$} & $\bar{x}$ & 2.2 & 2.3 \\
\hline & $S_{x}$ & 0.6 & 0.6 \\
\hline & $S_{\bar{x}}$ & 0.02 & 0.03 \\
\hline & $\mathrm{V}$ & 28.0 & 28.5 \\
\hline
\end{tabular}

* $\mathrm{S}=1 ; \mathrm{E}=2 ; \mathrm{U}=3 ; \mathrm{R}=4 ; \mathrm{O}=5 ; \mathrm{P}=6$; $* * 1=1 ; 2=2 ; 3=3 ; 4=4 ; 5=5$;

However these carcasses were fattier than Holstein carcasses (2.44 to 2.26 points). POLÁCH et al. (2004) compared the results of SEUROP system among 9 breeds. Holstein bulls got 3.53 points for conformation and 2.25 points for fatness. Czech Fleckvieh bulls obtained 3.27 points for conformation, which means a higher amount of animals classified into class " $U$ ".
The carcasses were better evaluated for fatness -1.91 points. Four age groups were made due to statistic database processing. The youngest bulls did not get 550 days at slaughtering. The second group formed bulls between 551-650 days. Bulls aged 451 to 700 days belonged to the third group and the last one was for animals older than 701 days.

II: The effect of aptitude on the conformation and fatness classes

\begin{tabular}{|c|c|c|c|c|}
\hline \multirow{2}{*}{ Breed } & \multirow{2}{*}{ SEUROP } & \multirow{2}{*}{$\mathbf{L S m e a n} \pm \mathbf{S E}$} & \multicolumn{2}{|c|}{ Significant difference } \\
\hline & & & $\mathrm{P}<\mathbf{0 . 0 5}$ & $\mathbf{P}<0.01$ \\
\hline Czech Fleckvieh & \multirow{2}{*}{ Conformation } & $2.872 \pm 0.025$ & \multirow{2}{*}{$1-2$} & \multirow{2}{*}{$1-2$} \\
\hline Holstein & & $3.093 \pm 0.046$ & & \\
\hline Czech Fleckvieh & \multirow{2}{*}{ Fatness } & $2.444 \pm 0.035$ & \multirow{2}{*}{$1-2$} & \multirow{2}{*}{$1-2$} \\
\hline Holstein & & $2.260 \pm 0.034$ & & \\
\hline
\end{tabular}


The statistically significant differences were demonstrated between the age groups of combine cattle. As is obvious in table III., the slaughtering age affect the final conformation classification of carcasses. Bulls ranked to higher age group go higher classifi- cation class. Statistically highly evidential difference $(\mathrm{P}<0,01)$ were found between groups $2-3$ and $2-4$, respectively between age group 551-650 days and groups $651-700$ and above 700 days.

III: The influence of the slaughter age on the conformation classes of Czech Fleckvieh and Holstein breed

\begin{tabular}{|c|c|c|c|c|c|}
\hline \multirow{2}{*}{$\begin{array}{c}\text { Slaughter age } \\
\text { (days) }\end{array}$} & \multirow{2}{*}{ n } & \multirow{2}{*}{ Breed } & \multirow{2}{*}{$\operatorname{LSmean} \pm \mathbf{S E}$} & \multicolumn{2}{|c|}{ Significant difference } \\
\hline & & & & $\mathrm{P}<\mathbf{0 . 0 5}$ & $\mathrm{P}<\mathbf{0 . 0 1}$ \\
\hline$<\mathbf{5 5 0}$ & 154 & \multirow{4}{*}{$\mathrm{C}$} & $3.110 \pm 0.034$ & \multirow{4}{*}{$2-3 ; 2-4$} & \multirow{4}{*}{$2-3 ; 2-4$} \\
\hline $551-650$ & 179 & & $3.092 \pm 0.018$ & & \\
\hline $651-700$ & 200 & & $2.988 \pm 0.020$ & & \\
\hline$>701$ & 170 & & $2.935 \pm 0.026$ & & \\
\hline$<550$ & 137 & \multirow{4}{*}{$\mathrm{H}$} & $3.406 \pm 0.058$ & \multirow{4}{*}{-} & \multirow{4}{*}{-} \\
\hline $551-650$ & 143 & & $3.208 \pm 0.037$ & & \\
\hline $651-700$ & 169 & & $3.139 \pm 0.040$ & & \\
\hline$>701$ & 193 & & $3.179 \pm 0.050$ & & \\
\hline
\end{tabular}

The dairy breed bulls did not show any statistically important difference among the groups. The middle error of the average is in both breeds very low - range from 0.02 to 0.05 . The fattiness classification did not show any significant differences in any group age. Average points value, or the classification classes given by a classifier, range for fatness from 2.21 to 2.34 points, which means most of the half carcasses were evaluated as class 2 "weakly fatty" (table IV.)
The carcasses weight was also divided into four groups for statistical evaluation. The heaviest group covered carcasses above $401 \mathrm{~kg}$. Among these weight groups was not proved any statistically important difference. Combine aptitude carcasses were classified the third conformation class, the class "U". The average points for conformation at individual groups ranged between 2.98 and 3.12 (table V.).

IV: The influence of the slaughter age on fatness classes of Czech Fleckvieh and Holstein bulls

\begin{tabular}{|c|c|c|c|c|c|}
\hline \multirow{2}{*}{$\begin{array}{c}\text { Slaughter age } \\
\text { (days) }\end{array}$} & \multirow{2}{*}{$\mathbf{n}$} & \multirow{2}{*}{ Breed } & \multirow{2}{*}{$\mathbf{L S m e a n} \pm \mathrm{SE}$} & \multicolumn{2}{|c|}{ Significant difference } \\
\hline & & & & $\mathrm{P}<\mathbf{0 . 0 5}$ & $\mathrm{P}<\mathbf{0 . 0 1}$ \\
\hline$<\mathbf{5 5 0}$ & 154 & \multirow{4}{*}{$\mathrm{C}$} & $2.217 \pm 0.096$ & \multirow{4}{*}{-} & \multirow{4}{*}{-} \\
\hline $551-650$ & 179 & & $2.302 \pm 0.051$ & & \\
\hline $651-700$ & 200 & & $2.375 \pm 0.058$ & & \\
\hline$>701$ & 170 & & $2.303 \pm 0.072$ & & \\
\hline$<\mathbf{5 5 0}$ & 137 & \multirow{4}{*}{$\mathrm{H}$} & $2.251 \pm 0.134$ & \multirow{4}{*}{-} & \multirow{4}{*}{-} \\
\hline $551-650$ & 143 & & $2.275 \pm 0.085$ & & \\
\hline $651-700$ & 169 & & $2.293 \pm 0.093$ & & \\
\hline$>701$ & 193 & & $2.339 \pm 0.115$ & & \\
\hline
\end{tabular}


V: The effect of the carcass weight on the conformation classes of Czech Fleckvieh and Holstein bulls

\begin{tabular}{|c|c|c|c|c|c|}
\hline \multirow{2}{*}{$\begin{array}{l}\text { Weight of } \\
\text { carcass (kg) }\end{array}$} & \multirow{2}{*}{$\mathbf{n}$} & \multirow{2}{*}{ Breed } & \multirow{2}{*}{$\mathrm{LS}$ mean $\pm \mathrm{SE}$} & \multicolumn{2}{|c|}{ Significant difference } \\
\hline & & & & $P<0.05$ & $\mathbf{P}<0.01$ \\
\hline$<310$ & 146 & \multirow{4}{*}{$\mathrm{C}$} & $3.125 \pm 0.030$ & \multirow{4}{*}{-} & \multirow{4}{*}{-} \\
\hline $311-360$ & 175 & & $2.985 \pm 0.017$ & & \\
\hline $361-400$ & 198 & & $3.011 \pm 0.020$ & & \\
\hline$>401$ & 184 & & $3.005 \pm 0.038$ & & \\
\hline$<310$ & 131 & \multirow{4}{*}{$\mathrm{H}$} & $3.51 \pm 0.053$ & \multirow{4}{*}{ - } & \multirow{4}{*}{-} \\
\hline $311-360$ & 143 & & $3.118 \pm 0.036$ & & \\
\hline $361-400$ & 164 & & $3.120 \pm 0.038$ & & \\
\hline$>401$ & 204 & & $3.182 \pm 0.052$ & & \\
\hline
\end{tabular}

The Holstein carcasses were less muscular compared to Czech Fleckvieh bulls, more of them were classified to class "R" for meatiness than Czech Fleckvieh. For that it can be estimated higher dependence between the carcass weight and conformation classification. More carcass weight in Holstein bulls leads to a better conformation evaluation, which is certainly logical. The fatness classification (table VI.) identified statistically significant differences $(\mathrm{P}<0.01)$ at the carcasses of Czech Fleckvieh between the weight group 1. (Weight to $310 \mathrm{~kg}$ ) and group 3. (weight 361 to $400 \mathrm{~kg}$ ). The Holstein carcasses did not show any statistically significant difference at fatness. The points value (the number of points corresponds to a quality class) for fatness class range from 2.054-2.483. CHLÁDEK and INGR (2003) assessed the influence of slaughtering weight on beef production. The animals slaughtered at higher weight were better evaluated for conformation together with higher proportion of the main beef parts.

VI: The effect of weight of carcass on fatness classes of Czech Fleckvieh and Holstein bulls

\begin{tabular}{|c|c|c|c|c|c|}
\hline \multirow{2}{*}{$\begin{array}{c}\text { Weight of } \\
\text { carcass }(\mathrm{kg})\end{array}$} & \multirow{2}{*}{$\mathbf{n}$} & \multirow{2}{*}{ Breed } & \multirow{2}{*}{ LSmean \pm SE } & \multicolumn{2}{|c|}{ Significant difference } \\
\hline & & & & $\mathrm{P}<\mathbf{0 . 0 5}$ & $\mathbf{P}<0.01$ \\
\hline$<310$ & 146 & \multirow{4}{*}{$\mathrm{C}$} & $2.054 \pm 0.018$ & \multirow{4}{*}{$1-3$} & \multirow{4}{*}{$1-3$} \\
\hline $311-360$ & 175 & & $2.211 \pm 0.021$ & & \\
\hline $361-400$ & 198 & & $2.483 \pm 0.014$ & & \\
\hline$>401$ & 184 & & $2.154 \pm 0.038$ & & \\
\hline$<310$ & 131 & \multirow{4}{*}{$\mathrm{H}$} & $2.195 \pm 0.123$ & \multirow{4}{*}{-} & \multirow{4}{*}{-} \\
\hline $311-360$ & 143 & & $2.310 \pm 0.082$ & & \\
\hline $361-400$ & 164 & & $2.288 \pm 0.088$ & & \\
\hline$>401$ & 204 & & $2.365 \pm 0.119$ & & \\
\hline
\end{tabular}

The table VII. shows the relations between the SEUROP system and net daily gain. The first group includes bulls with the lowest net daily gain - to 500 g.day $^{-1}$. Bulls of the last group reached over 651 g.day $^{-1}$. The statistical data processing proved high important differences of conformation in Czech Fleckvieh carcasses - groups 1-4. High important difference $(\mathrm{P}<0.01)$ was proved among net daily gain to 500 g. day ${ }^{-1}$ and 551-600 g.day ${ }^{-1}$ and the absolute daily gain exceeding 651 g.day ${ }^{-1}$. The significant differences were also found for the evaluation of Holstein carcasses conformation. Statistically important differences $(\mathrm{P}<0.01)$ were proved between the groups 1 and $3,4,5$. 
VII: The effect of the daily net weight gain on the conformation classes of Czech Fleckvieh and Holstein bulls

\begin{tabular}{|c|c|c|c|c|c|}
\hline \multirow{2}{*}{$\begin{array}{c}\text { Daily net } \\
\text { weight gain (g) }\end{array}$} & \multirow{2}{*}{$\mathbf{n}$} & \multirow{2}{*}{ Breed } & \multirow{2}{*}{$\operatorname{LSmean} \pm \mathbf{S E}$} & \multicolumn{2}{|c|}{ Significant difference } \\
\hline & & & & $\mathrm{P}<0.05$ & $\mathbf{P}<0.01$ \\
\hline$<\mathbf{5 0 0}$ & 123 & \multirow{5}{*}{$\mathrm{C}$} & $3.139 \pm 0.028$ & \multirow{5}{*}{$1-3,1-4,1-5$} & \multirow{5}{*}{$1-3,1-5$} \\
\hline $501-550$ & 146 & & $3.045 \pm 0.021$ & & \\
\hline $551-600$ & 174 & & $2.993 \pm 0.020$ & & \\
\hline $601-650$ & 213 & & $2.995 \pm 0.029$ & & \\
\hline$>651$ & 170 & & $2.985 \pm 0.036$ & & \\
\hline$<\mathbf{5 0 0}$ & 110 & \multirow{5}{*}{$\mathrm{H}$} & $3.515 \pm 0.052$ & \multirow{5}{*}{$1-2,1-3,1-4,1-5$} & \multirow{5}{*}{$1-3,1-4,1-5$} \\
\hline $501-550$ & 104 & & $3.280 \pm 0.041$ & & \\
\hline $551-600$ & 169 & & $3.149 \pm 0.038$ & & \\
\hline $601-650$ & 132 & & $3.106 \pm 0.041$ & & \\
\hline$>651$ & 127 & & $3.113 \pm 0.052$ & & \\
\hline
\end{tabular}

The difference in net daily gain for groups 1 and 2 was located with a $95 \%$ probability. The analyses of net daily influence on the fattiness classification did not prove any conclusive difference between the grades of net daily gain at any monitored aptitude (table VIII.). BJELKA et al. (2002) published that higher net gain of slaughtered animals agree with higher feeding intensity. As the result is a positive connection between net gain and conformation class. This identical tendency is noticeable from the results written in the table VII. The fatness evaluation showed the opposite relation.

VIII: The effect of the daily net weight gain on the fatness classes of Czech Fleckvieh and Holstein bulls

\begin{tabular}{|c|c|c|c|c|c|}
\hline \multirow{2}{*}{$\begin{array}{c}\text { Daily net } \\
\text { weight gain }\end{array}$} & \multirow{2}{*}{$\mathbf{n}$} & \multirow{2}{*}{ Breed } & \multirow{2}{*}{$\operatorname{LSmean} \pm \mathrm{SE}$} & \multicolumn{2}{|c|}{ Significant difference } \\
\hline & & & & $\mathrm{P}<\mathbf{0 . 0 5}$ & $\mathbf{P}<\mathbf{0 . 0 1}$ \\
\hline$<\mathbf{5 0 0}$ & 123 & \multirow{5}{*}{$\mathrm{C}$} & $2.206 \pm 0.080$ & \multirow{5}{*}{-} & \multirow{5}{*}{ - } \\
\hline $501-550$ & 146 & & $2.258 \pm 0.059$ & & \\
\hline $551-600$ & 174 & & $2.324 \pm 0.057$ & & \\
\hline $601-650$ & 213 & & $2.367 \pm 0.083$ & & \\
\hline$>651$ & 170 & & $2.342 \pm 0.102$ & & \\
\hline$<500$ & 110 & \multirow{5}{*}{$\mathrm{H}$} & $2.043 \pm 0.119$ & \multirow{5}{*}{-} & \multirow{5}{*}{-} \\
\hline $501-550$ & 104 & & $2.247 \pm 0.094$ & & \\
\hline $551-600$ & 169 & & $2.338 \pm 0.087$ & & \\
\hline $601-650$ & 132 & & $2.442 \pm 0.096$ & & \\
\hline$>651$ & 127 & & $2.376 \pm 0.120$ & & \\
\hline
\end{tabular}

The last searched factor was the influence of farming conditions. Czech Fleckvieh bulls were from eleven farms and Holsteins were fattening up in 8 farms. The feeding level at a particular farm can be estimated by this factor analysis. The table IX. shows the highly important difference of Czech Fleckvieh conformation at the majority of the farms while Holstein bulls did not prove it. Similar trend (statistical differences only in Czech Fleckvieh) is expressed in table $\mathrm{X}$., where is evaluated fatness in relation to the farms.
A work with similar information was published by ŠUBRT et al. (2004), where the influence of 16 farms on the final conformation and fatness classification at the Czech Fleckvieh in the East of Bohemia. The conformation classification did not prove any important differences among the farms. The average points for conformation were 3.57. The important difference $(\mathrm{P}<0.01)$ among the feeders was due to various fattening intensity and slaughtering at later age, the authors proved at the fatness classification. 
IX: The effect of the farm on the conformation classes of Czech Fleckvieh and Holstein bulls

\begin{tabular}{|c|c|c|c|c|c|}
\hline \multirow{2}{*}{ Farm } & \multirow{2}{*}{$\mathbf{n}$} & \multirow{2}{*}{ Breed } & \multirow{2}{*}{$\mathbf{L S m e a n} \pm \mathbf{S E}$} & \multicolumn{2}{|c|}{ Significant difference } \\
\hline & & & & $\mathrm{P}<0.05$ & $\mathrm{P}<0.01$ \\
\hline 1 & 43 & \multirow{11}{*}{$\mathrm{C}$} & $2.196 \pm 0.090$ & \multirow{11}{*}{$\begin{array}{c}1-9 ; 2-9 ; 3-9 ; \\
\text { 4-9; 5-9; 6-9; } \\
\text { 7-9; 8-9; 9-9; } \\
\text { 10-9; 11-9; }\end{array}$} & \multirow{11}{*}{$\begin{array}{c}1-9 ; 2-9 ; 3-9 ; \\
4-9 ; 5-9 ; 6-9 ; \\
7-9 ; 8-9 ; 9-9 ; \\
10-9 ; 11-9 ;\end{array}$} \\
\hline 2 & 37 & & $2.001 \pm 0.090$ & & \\
\hline 3 & 62 & & $2.310 \pm 0.074$ & & \\
\hline 4 & 69 & & $2.253 \pm 0.096$ & & \\
\hline 5 & 51 & & $2.417 \pm 0.100$ & & \\
\hline 6 & 85 & & $2.273 \pm 0.060$ & & \\
\hline 7 & 93 & & $2.830 \pm 0.075$ & & \\
\hline 8 & 54 & & $2.120 \pm 0.074$ & & \\
\hline 9 & 85 & & $2.374 \pm 0.100$ & & \\
\hline 10 & 48 & & $2.137 \pm 0.080$ & & \\
\hline 11 & 76 & & $2.382 \pm 0.177$ & & \\
\hline 1 & 56 & \multirow{8}{*}{$\mathrm{H}$} & $3.289 \pm 0.038$ & \multirow{8}{*}{-} & \multirow{8}{*}{-} \\
\hline 2 & 92 & & $3.134 \pm 0.063$ & & \\
\hline 3 & 88 & & $3.256 \pm 0.025$ & & \\
\hline 4 & 82 & & $3.504 \pm 0.079$ & & \\
\hline 5 & 113 & & $3.035 \pm 0.101$ & & \\
\hline 6 & 98 & & $3.177 \pm 0.047$ & & \\
\hline 7 & 79 & & $3.242 \pm 0.161$ & & \\
\hline 8 & 34 & & $3.226 \pm 0.087$ & & \\
\hline
\end{tabular}

X: The effect of the farm on fatness classes of Czech Fleckvieh and Holstein bulls

\begin{tabular}{|c|c|c|c|c|c|}
\hline \multirow{2}{*}{ Farm } & \multirow{2}{*}{$\mathbf{n}$} & \multirow{2}{*}{ Breed } & \multirow{2}{*}{$\mathrm{LS}$ mean $\pm \mathrm{SE}$} & \multicolumn{2}{|c|}{ Significant difference } \\
\hline & & & & $\mathbf{P}<0.05$ & $\mathbf{P}<0.01$ \\
\hline 1 & 43 & \multirow{11}{*}{$\mathrm{C}$} & $2.994 \pm 0.032$ & \multirow{11}{*}{$\begin{array}{c}1-7 ; 2-7 ; 3-7 ; \\
4-7 ; 6-7 ; 7-8 ; \\
7-10 ;\end{array}$} & \multirow{11}{*}{$\begin{array}{c}1-7 ; 2-7 ; 3-7 ; \\
4-7 ; 6-7 ; 7-8 ; \\
7-10 ;\end{array}$} \\
\hline 2 & 37 & & $3.007 \pm 0.032$ & & \\
\hline 3 & 62 & & $3.003 \pm 0.026$ & & \\
\hline 4 & 69 & & $2.969 \pm 0.034$ & & \\
\hline 5 & 51 & & $3.051 \pm 0.036$ & & \\
\hline 6 & 85 & & $3.114 \pm 0.021$ & & \\
\hline 7 & 93 & & $3.004 \pm 0.027$ & & \\
\hline 8 & 54 & & $3.003 \pm 0.026$ & & \\
\hline 9 & 85 & & $3.328 \pm 0.035$ & & \\
\hline 10 & 48 & & $3.003 \pm 0.028$ & & \\
\hline 11 & 76 & & $2.869 \pm 0.063$ & & \\
\hline 1 & 56 & \multirow{8}{*}{$\mathrm{H}$} & $2.291 \pm 2.291$ & \multirow{8}{*}{-} & \multirow{8}{*}{ - } \\
\hline 2 & 92 & & $2.735 \pm 0.144$ & & \\
\hline 3 & 88 & & $2.303 \pm 0.058$ & & \\
\hline 4 & 82 & & $3.198 \pm 0.183$ & & \\
\hline 5 & 113 & & $1.918 \pm 0.233$ & & \\
\hline 6 & 98 & & $2.278 \pm 0.108$ & & \\
\hline 7 & 79 & & $1.828 \pm 0.371$ & & \\
\hline 8 & 34 & & $1.764 \pm 0.199$ & & \\
\hline
\end{tabular}




\section{CONCLUSION}

The aim of the work was to specify the influence rate of the SEUROP system by the appropriate aptitude selection, slaughtering age, carcass weight, net daily gain as well as the difference between beef production farms. More statistically important differences were found at Czech Fleckvieh bulls, particularly the difference between age groups in relation to the carcass conformation class. Further indicator with high important differences in conformation was the level of net daily gain. Significant number of evidential differences was proved among the farms, where it shows to various fattening intensity and feeding dissimilarity. The influence of net daily gain on conformation classification was detected in Holstein breed.

\section{SOUHRN}

Biologické faktory ovlivňující klasifikaci jatečných býků českého strakatého a holštýnského skotu v systému SEUROP

Cílem práce bylo posoudit vliv zvolených efektů (užitkového typu, věku zviŕat v době porážky, hmotnosti jatečně upraveného těla, úrovně netto př́růstku a vlivu výkrmce) na výslednou klasifikaci jatečných těl býků v systému SEUROP. K analýze bylo použito 703 býků českého strakatého a 642 býků holštýnského plemene. Všechna zvířata byla poražena a hodnocena $\mathrm{v}$ jednom závodě masného průmyslu. Významné diference $v$ rámci sledovaných faktorů byly zjištěny převážně u jatečných těl býků kombinovaného užitkového typu. Vysoce signifikantní rozdíly průměrů skupin $(\mathrm{P}>0,01)$ byly stanoveny mezi jednotlivými farmami a uvedené diference vyplývají zejména z odlišných podmínek výkrmu jatečných zvírat. Významné rozdíly byly také zjištěny mezi jednotlivými užitkovými typy a hladinami netto př́růstku. U býků plemene Holštýn byly zjištěny vysoce signifikantní diference $(\mathrm{P}<0,01)$ mezi úrovní netto př́růstku do 500 g.den ${ }^{-1}$ a úrovněmi 551 až 600; 601-650 a nad 651 g.den ${ }^{-1}$. Ze zvolených faktorů má na klasifikaci v SEUROP systému nejvyšší vliv užitkový typ a úroveň výživy zviřat, která je v práci vyjádřena výší netto prrírůstku a efektem vliv farmy.

SEUROP, zmasilost, protučnělost, skot, užitkový typ, věk a hmotnost v době porážky

Supported by the Ministry of Agriculture of the Czech Republic (Project NO. QF4005).

\section{REFERENCES}

AUGUSTINI, C., BRANTSCHEID, W., SCHWARZE, F. J., KIRCHGESSNER, M.: Wachstumsspezifische Veränderung der Schlachtkörperqualität von Mastrindern der Rasse Deutsches Fleckvieh. Fleischwirtschaft, 1992, 72, 1584-1589. ISSN: 0015$363 \mathrm{X}$

BJELKA, M., ŠUBRT, J., POLÁCH, P., KRESTÝNOVÁ, M., UTTENDORFSKÝ, K.: Carcass quality in crossbred bulls in relation to SEUROP system grading. Czech J. Anim. Sci., 2002, 47, 11, 467475. ISSN 1212-1819

BUREŠ, D., BARTOŇ, L., TESLÍK, V., ZAHRÁDKOVÁ, R., KREJČOVÁ, M.: Kvalita jatečných těl býků, krav a jalovic v jednotlivých třídách zmasilosti SEUROP. Aktuální otázky produkce jatečných zvírat . MZLU v Brně, 2004, 64-69, ISBN 80-7157-783-9.

CICALA, C., CIRINO, G.: Linkage between inflammation and coagulation: An update on the molecu- lar basis of the crosstalk. Life sciences, 1998, 62, 20, 1817-1824. ISSN: 0024-3205

ČUBOŇ, J., NOSÁL, V., MOJTO, J.: Classification of carcass structure of bulls and Heifer in EUROP system. Czech J. Anim. Sci., 2000, 45, 8, 367-372. ISSN 1212-1819

FIEMS, L. O., DE CAMPENEERE, S., BOGAERTS, D. F., COTTYN, B. G., BOUCQUE C. V.: The influence of dietary energy and protein levels on performance, carcass and meat quality of Belgian White-blue double-muscled finishing bulls. Animal science, 1998, 66, 2, 319-327. ISSN: 13577298

GERHARDY, H.: Investigation of a market led young bull beef-production system red Holstein-friesian, Fleckvieh, Limousine and Belgian-blue crossbreds. Züchtungskunde, 1994, 66, 4, 281-296. ISSN: 0044-5401

CHAMBAZ, A., SCHEEDER, M. R. L., KREUZER, M., DUFEY, P. A.: Meat quality of Angus, Simmental, Charolais and Limousine steers compared at 
the same intramuscular fat content. Meat Science, 2003, 63, 491-500. ISSN: 0309-1740

CHLÁDEK, G., INGR, I.,: The effect of slaughter weight and growth rate on meat performance of Holstein steers. Czech J. Anim. Sci., 2003, 48, 8, 331-337. ISSN 1212-1819

KÖGEL, J.: Das „Idealgewicht“ des Flekviehbullen. Tierzuchter, 1990, 42, 287-289. ISSN: 0040-7364

MANDELL, I. B., GULLETT, E. A., WILTON, J. W., ALLEN, O. B., KEMP, R. A.: Effects of breed and dietary energy content within breed on growth performance, carcass and chemical composition and beef quality in Hereford and Simmental steers. Canadian Journal of Animal Science, 1998, 78, 4, 533-541. ISSN: 0008-3984

ONEC, A.: A comparison of Holstein Friesian, Brown Weiss and Eastern Anatolian Red cattle slaughtered in Turkey for carcass conformation and fatness in
SEUROP system. Czech J. Anim. Sci., 2004, 49, 4, 169-176. ISSN 1212-1819

PIPEK, P., HEBERL, A., JELENÍKOVÁ, J.: Influence of slaughterhouse on the quality of beef carcasses. Czech J. Anim. Sci., 2003, 48, 9, 371-378. ISSN 1212-1819

POLÁCH, P., ŠUBRT, J., BJELKA, M., UTTENDORFSKÝ, K., FILIPČÍK, R.: Carcass value of the progeny of tested beef bulls. Czech J. Anim. Sci., 2004, 49, 7, 315-322. ISSN 1212-1819

ŠUBRT, J., LANGR, J., FILIPČÍK, R., ŠTEFUNKA, F.: Vliv farmy a výše porážkové hmotnosti býků českého strakatého plemene na výsledné parametry masné užitkovosti. Aktuální otázky produkce jatečných zvířat. 2004, 70-76, ISBN 80-7157-783-9.

ŠUBRT, J., FRELICH, J., POLÁCH, P., VOŘÍŠKOVÁ, J.: Analysis of carcass quality in sons of breeding bulls of meat breeds. Czech J. Anim. Sci., 1999, 44, 1, 39-48. ISSN 1212-1819

Ing. Radek Filipčík, Prof. Ing. Jan Šubrt, CSc., Ing. Martin Vyroubal, Ústav chovu a šlechtění zvířat, Mendelova zemědělská a lesnická univerzita v Brně, Zemědělská 1, 61300 Brno, Česká republika, e-mail: filipcikr@ seznam.cz 
